\title{
Gender Roles and Economic Differentials in Aquaculture of Kainji Lake Basin, Nigeria
}

\author{
Julius Emeka Omeje 1 $^{*}$ Anthonia Ifeyinwa Achike ${ }^{2}$ Attahiru Mohammed Sule $^{3}$ Chukwue- \\ meka John Arene ${ }^{2}$
}

1. National Institute for Freshwater Fisheries Research New Bussa, Niger State Nigeria

2. Department of Agricultural Economics, University of Nigeria, Nsukka

3. Division of Socio-economics and Extension, National Institute for Freshwater Fisheries, Nigeria

\begin{tabular}{|c|c|}
\hline ARTICLE INFO & ABSTRACT \\
\hline Article history & \multirow{14}{*}{$\begin{array}{l}\text { The existing power differences among men, women and youths in aqua- } \\
\text { culture pre-empted the study on gender roles and economic differentials } \\
\text { in aquaculture of Kainji Lake Basin, Nigeria. Specifically, the study as- } \\
\text { sessed sources of production resources, gender roles, cost and returns and } \\
\text { existing gender gaps in aquaculture. Using a survey design, a two-stage } \\
\text { sampling procedure was used to select } 81 \text { males and } 39 \text { females from a } \\
\text { population of } 229 \text { fish farmers. Data were presented using descriptive sta- } \\
\text { tistics and analyzed with budgetary technique and gender gap ratios. Key } \\
\text { result shows that the men and youths had direct access to land through } \\
\text { inheritance and purchase while the women (61\%) accessed land through } \\
\text { a family relation. The men and male youths performed majority of the } \\
\text { gender roles involved in preparation of ponds, fingerlings stocking, fish } \\
\text { management and post-harvest activities while the women and female } \\
\text { youths were actively involved in fish management, liming and grading. } \\
\text { Economic indicators show that the men and youths have a higher return } \\
\text { on investment than the women implying that such power differences } \\
\text { still exist. Hence, it is recommended that women should be organized in } \\
\text { groups for empowerment. This will enable them utilize their collective } \\
\text { strength through division of labour in fish farming. }\end{array}$} \\
\hline Received: 23 April 2021 & \\
\hline Accepted: 27 May 2021 & \\
\hline Published Online: 31 May 2021 & \\
\hline Keywords: & \\
\hline Gender & \\
\hline Aquaculture & \\
\hline Aquacuiture & \\
\hline Catfish & \\
\hline Economic & \\
\hline Men & \\
\hline Women & \\
\hline & \\
\hline Youths & \\
\hline
\end{tabular}

\section{Introduction}

Gender, a social construct which determines the roles of men, women and youths in a given society is highly relevant in the development of aquaculture in Nigeria. This is because the men and women play key roles along the value chain. According to Kumar, Eagle and Tucker (2018), the aquaculture sector is male dominated because of the capital intensive nature and the technologies associated with its development. However, the roles of women are observed in every link of

the aquaculture value chain, notably in the processing and marketing of fish, fisheries resource management and policy decision making (Lentisco \& Lee, 2015). In Bangladesh for instance, women perform most of the routine operations such as fertilization of ponds and fish feeding as well as other day-to-to operations. In several cases, they harvest fish for family consumption with the help of their children while the husbands (men) only help when the water in the ponds is too deep, requiring more specialized gear to be used for fish harvesting (Quddus, Jui, Rahman \& Rahman, 2017). In

*Corresponding Author:

Julius Emeka Omeje;

juliusomeje@gmail.com 
Nigeria, Aguihe, Sule \& Olowosegun (2013) reported that the men carry out almost all the processes in breeding and management of improved catfish in kainji Lake Basin while the women were only involved in feeding of fry's/fingerlings. Thus, implying that these gender roles vary across place, society and family settings.

It is widely recognized that women's engagement in aquaculture is numerous, significantly contributing to the overall well-being of household members; however, their contributions are not commensurate with the return they get because of deep-rooted gender disparities in social, cultural and economic spheres (Harrisson, Leitch \& McAdam, 2016). Gender in one way or the other, affects the distribution of labour, resources, wealth, decision-making, political power as well as the enjoyment of rights and entitlements within the family as well as in public life (Paul \& Meena, 2016). According to Kenya Market-led Aquaculture Programme [KMAP], (2016), women face stiffer constraints in access and use of production resources than their male counterparts who are heads of households. Statistics shows a significant difference in gender access to production resources (Ayodele, Fasina \& Awoyemi, 2016). These uneven access to production resources and unequal distribution of return between men and women means that the development of aquaculture does not benefit the whole gender community as expected. On this note, Kruijssen et al. (2018) proposed a gender perspective in value chain analysis to address the issue of gender differences in aquaculture and increase the output and benefits associated with the business. This involves the assessment of gender roles of men, women and youths, and how they inter-relate with each other; which provides the possibilities of counteracting constraints and gain the maximum benefits from the aquaculture business.

Gender issues in aquaculture needs to be addressed squarely through the exposure of women and youths to equal access to production resources like the men (Gallant, 2019). Addressing this gap is of particular relevance to the growth of aquaculture sub-sector which has become a significant economic sector. Aquaculture is reported to have a notable economic potential to contribute to women's economic and social empowerment as well as bring about gender equality and economic development (Manyung-Pasani, Hara \& Chimatiro, 2017). Although, Ferrer, Perez, Roxas \& Avila (2014) reported that men and women complement each other in reproductive and productive roles; Brugere \& Williams. (2017) noted that women tend to lose their control over economic activities as aquaculture production grows thereby making them lose out from the benefits from the aquaculture boom. The above observation informed the need for this study especially, the dearth in information on gender roles and economic differences of men, women and youths in aquaculture of Kainji lake basin, Nigeria. Specifically, the study assessed the sources of production resources, examined gender roles and the perceptions of respondents to participation in fish culture, estimated the cost and returns of men, women and youths as well as the corresponding gender gaps in aquaculture of Kainji Lake Basin Nigeria.

\section{Methodology}

\subsection{Study area}

The study was conducted in Kainji Lake Basin, an area in the south of Niger State and north of Kebbi State, Nigeria. The area is located between Latitudes $9^{\circ} 50^{\prime}$ and $1^{\circ} 55^{\prime}$ 'North and Longitudes $4^{\circ} 23^{\prime}$ and $4^{\circ} 51^{\prime}$ 'East (Omeje, Achike, Arene, Ifejika \& Ifeijika, 2020). The lake is divided into three strata; upper stratum, middle stratum and lower stratum. The upper and middle strata are dominated by fisher men (capture fisheries) while the lower stratum is dominated by fish farmers or aquaculture with catfish the most cultured fish species. There are about 362 fishing communities around the lake; whereas, capture fisheries and aquaculture is one of the major economic activities of the inhabitants around the lake.

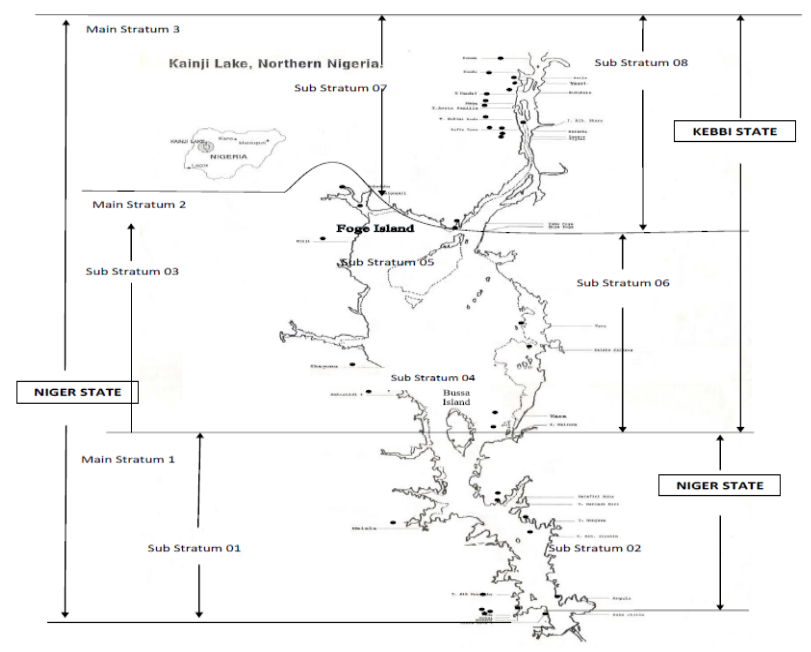

Figure. Map of Kainji Lake Basin

Source: Sule, Olowosegun, Sanni, Landu and Tanko, (2015)

\subsection{Sampling and data collection}

A two-stage sampling procedure was adopted in the selection of 120 ( 81 males and 39 females) respondents from a population of 229 table-size fish farmers. The 
first stage involved the purposive selection of 20 communities based on the preponderance of fish farmers. The communities include; New bussa, Yauri, Rofia, Kokoli, Zamare, Utonu, Duga, T. Gungawa, Musawa, Gafara, Wawu, Wara, Monai, T. A. Danbaba, Malale, Mahuta, T/Na'ilo, Shagunu, Mashaya, and Cover Dam. The second stage involved the proportional selection of 20 fish farmers each from Monai and New bussa, 15 from Malale, 10 each from Shagunu and Kokoli and three each from Yauri, Rofia, Mahuta, Zamare, Utonu, Duga, Mashaya, T. Gungawa, Gafara, Wawu, Wara, T. A. Danbaba, Musawa, T/Na'ilo and Cover Dam, making a total of 120 table-size fish farmers. The sample frame used for the selection was retrieved from registered members of the fish farmer's association in the area. Data were sex-disaggregated and categorized into 3 major groups. The first and second groups were the men and women who were males or females above 35 years of age while the third group comprise of the youths who were male and female below 35 years of age.

\subsection{Data analysis and model specification}

Data were presented using descriptive statistics such as mean, percentage, likert-type scale and pie charts. Also, data were analyzed using budgetary technique and gender gap ratio analysis as adopted by (Maltschnig, Pailer, Sirlinger \& Waltner, 2015). The models are specified as thus;

\subsection{Profitability indices}

Net Income after Tax (NIAT)

NIAT $=$ Revenue-Total expenses

Net Profit Margin

Net Profit Margin $=\frac{\text { Profit after tax }}{\text { Revenue }} * 100$

Where: Revenue $=$ Unit Price* Quantity supplied

Cost of Goods sold $=$ Cost of processing fish in a month

Return on Investment

Return on Investment $=\frac{\text { Net income after tax }}{\text { Total Expenses }} * 100$

\subsection{Gender gap analysis}

These are indicators that correlate two reference values through a simple calculation rule. Instead of just showing information on gender, it is possible, by calculating gender-specific ratios, to highlight differences between men, women and youths more clearly, thus making gender-sensitive statistics more informative (Maltschnig, Pailer,
Sirlinger \& Waltner, 2015). Key ratios include gender gaps (absolute gender gap and relative gender gap) and gender ratios.

Absolute gender gap $=$ Differences in values for men, women and youths in absolute terms

Relative gender gap $=\left(\frac{\mathrm{ai}}{\mathrm{bi}}-1\right) * 100$

Gender ratio $=\frac{\mathrm{ai}}{\mathrm{bi}}$

Where; ai=values for men, women and youths $\mathrm{bi}=\mathrm{values}$ for men, women and youths

\section{Results and Discussion}

\subsection{Socio-economic characteristics of fish farmers}

The result on socio-economic characteristics of the fish farmers is presented in Table 1 . The results show that majority of the men $(54.74 \%)$ and women (56.12 $\%)$ were within the age bracket of 41-50 years while majority $(76.82 \%)$ of the youths were within the age bracket of 21-30 years. This shows that majority of the farmers were still in their economic active age which corresponds to the finding of Akarue and Aregbor (2015) that majority ( $74.72 \%$ ) of fish farmers in Delta state were within the age bracket of 21-40 years. This indicates how lucrative fish farming is in the area which has become attractive to "young aged" actors as reported by Ifejika et al. (2015). Furthermore, majorities $92.12 \%, 100 \%$ and $74.67 \%$ of the men, women and youths respectively, were married while the mean years of experience was $8.90,5.00,4.86$ respectively. This result corresponds to the result of Ukpe, Audu, 1 Djomo \& Akise (2017) who reported that $60 \%$ of fish farmers in Taraba state had experience of 6-10 years. This is a good sign in the fish farming value chain as the result shows that the fish farmers have a good number of years of experience in managing risks and others shocks that can possibly affect the business. Finally, findings show that the men (49.64\%), women (44.21 $\%)$ and youths (67.99\%) had tertiary educational qualification. A high literacy level in fish farming have been established to enhance the management of fish farms through the adoption of improved farm practices (Ogunmefun \& Achike, 2017). The high literacy level in the area could be attributed to the presence of higher academic and research institutions such as Federal College of Freshwater Fisheries Technology, Federal college of wildlife management and NIFFR. Hence, graduates and trainees from these institutions must have put their knowledge into practice. 
Table 1. Socio-economic Characteristics of Fish Farmers

\begin{tabular}{|c|c|c|c|c|c|c|}
\hline & $\begin{array}{c}\text { Men } \\
(\mathrm{N}=64)\end{array}$ & & $\begin{array}{l}\text { Women } \\
(\mathrm{N}=10)\end{array}$ & & $\begin{array}{l}\text { Youths } \\
(\mathrm{N}=46)\end{array}$ & \\
\hline & Percent & Mean & Percent & Mean & Percent & Mean \\
\hline Age & & 44.56 & & 42.90 & & 29.89 \\
\hline $21-30$ & 0.00 & & 0.00 & & 76.82 & \\
\hline $31-40$ & 32.31 & & 36.49 & & 23.18 & \\
\hline $41-50$ & 54.74 & & 56.12 & & 0.00 & \\
\hline$>50$ & 12.95 & & 7.39 & & 0.00 & \\
\hline \multicolumn{7}{|c|}{ Marital Status } \\
\hline Married & 92.12 & & 100.00 & & 74.67 & \\
\hline Single & 7.88 & & 0.00 & & 25.33 & \\
\hline Experience & & 8.90 & & 5.00 & & 4.86 \\
\hline $1-5$ & 23.47 & & 65.32 & & 66.84 & \\
\hline $6-10$ & 59.31 & & 29.73 & & 31.52 & \\
\hline $11-15$ & 12.09 & & 4.95 & & 1.64 & \\
\hline$>15$ & 5.13 & & 0.00 & & 0.00 & \\
\hline \multicolumn{7}{|c|}{ Level of Education } \\
\hline Primary & 21.43 & & 26.58 & & 11.67 & \\
\hline Secondary & 28.93 & & 29.21 & & 20.34 & \\
\hline Tertiary & 49.64 & & 44.21 & & 67.99 & \\
\hline
\end{tabular}

Source: Field survey, 2020

\subsection{Sources of finance and production resources}

The information on the various sources of finance for the men, women and youths (figure 1-3) shows that the men $(59 \%)$ and youths $(63 \%)$ used personal savings to finance their fish farming business while majority $(70 \%)$ of the women financed their fish farming business through the help of a family relation or friend. This shows the level of dependence of women on their spouses and family relations in financing their economic enterprise such as fish farming. Furthermore, this indicates the poor level of accessibility to formal credit institutions by the men, women and youths in the area. Thus, necessitating the need for the fish farmers to explore existing agricultural credit schemes such as the Agricultural Credit Guarantee Scheme Fund (ACGSF) as reported by Omeje, Nwabeze, Ifejika, Faleke \& Jimmy (2018) as well as the Anchor Borrower Programme of the Central Bank of Nigeria. This is because formal credit has shown to impact positively on outputs of agricultural commodities (Chandio, Yuansheng, Sahito \& Larik, 2016). However, the utilization of this formal source of finance depends on the ease of access. As indicated in Table 2, the men, women and youths indicated that it is difficult $(>1.5)$ to access credit from commercial banks, money lenders and cooperative societies. However, the men and youths indicated that it is easy $(<1.5)$ to access funding from family and friends while the women on the other hand, indicated that it is difficult to access fund from family and friends even though it was their major source of finance. This suggests that the women have to lobby or persuade their spouse and family relations to release fund for investment in fish farming.

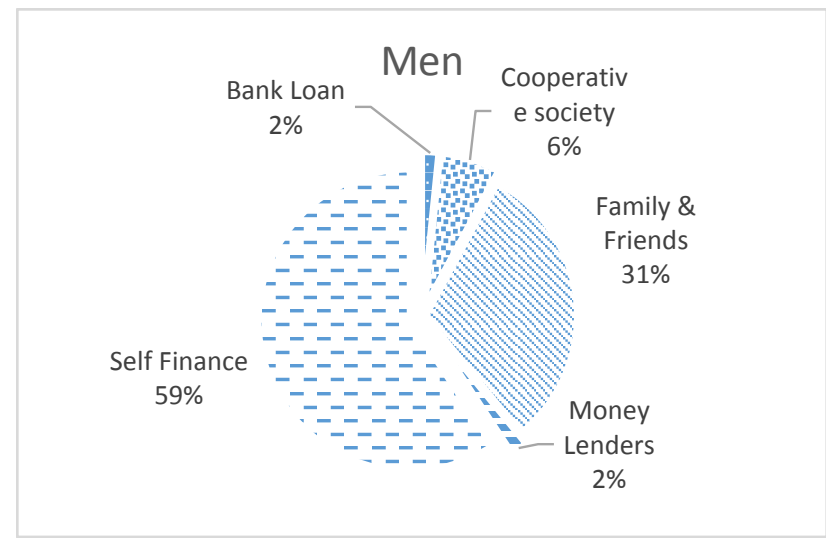

Figure 1

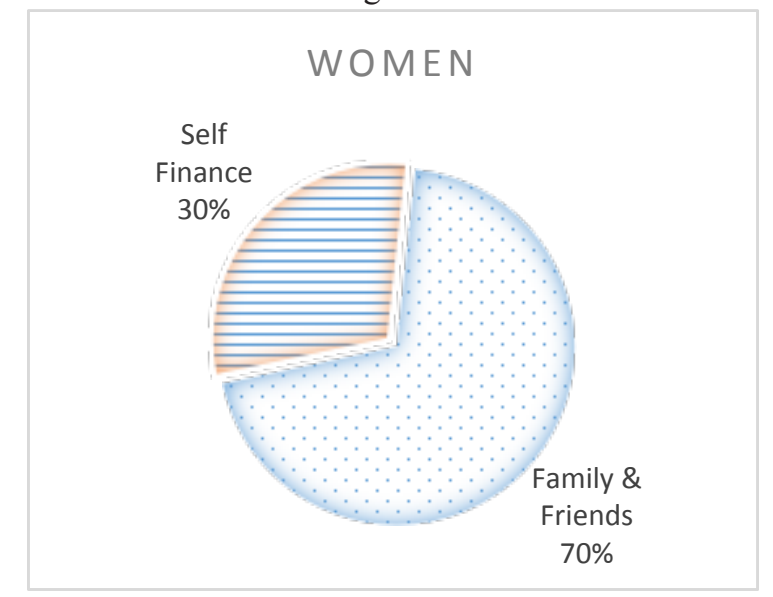

Figure 2

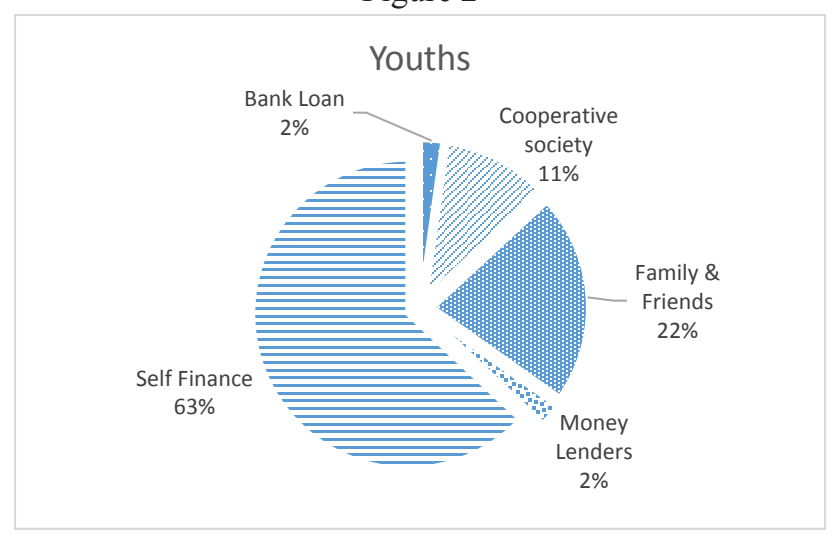

Figure 3

Figure 1-3. Sources of finance used in fish farming

Table 2. Ease of access to loan

\begin{tabular}{cccc}
\hline Source & Men & Women & Youths \\
\hline Bank Loan & 2.29 & 2.00 & 2.10 \\
Money Lenders & 1.91 & 1.70 & 2.02 \\
Cooperative societies & 1.85 & 1.70 & 1.78 \\
Family and Friends & 1.31 & 1.60 & 1.39 \\
\hline
\end{tabular}

Source: Field Survey, 2020

Note: $<1.5=$ easily, $>1.5$ Difficult

Furthermore, result in figure 4-6 shows that the men 
(37\%) and the youths (38\%) use lands that were acquired through inheritance and purchase respectively, while majority $(61 \%)$ of the women use lands belonging to a family relation (their spouses). In Nigeria, it is reported that less than $16 \%$ of women have explicit land rights and ownership (FAOSTAT, 2020). Moreover, FAO (2011) reported that closing gender gap in land holdings will require a holistic approach through land reforms, strategies, policies and legislation within existing socio-cultural norms. This is because most traditional institutions favour men than women in land allocations. In most cases, women have access to land through their relationships with a relative or through marriage where they use lands belonging to their husbands. Another impeding factor to women's land ownership especially in Northern Nigeria like the Kainji Lake Basin is the practice of purdar system (women seclusion). The systems impede women from engaging in direct or highly labourious agricultural activity because of the religious belief system. Thus, the men tend to participate in activities such as outdoor fish farming and other labourious agricultural activities (Gambo, Zahran \& Sidahmed, 2016); thereby placing them at an advantage over women in land ownership.

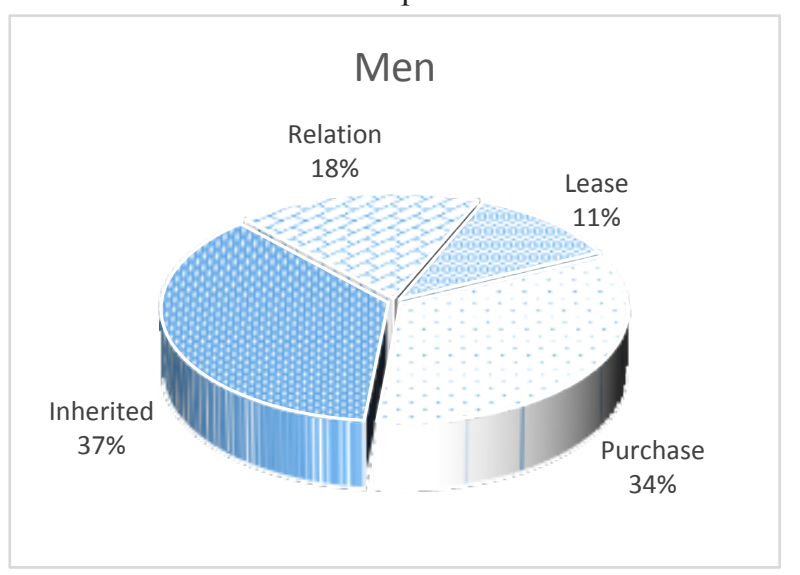

Figure 4

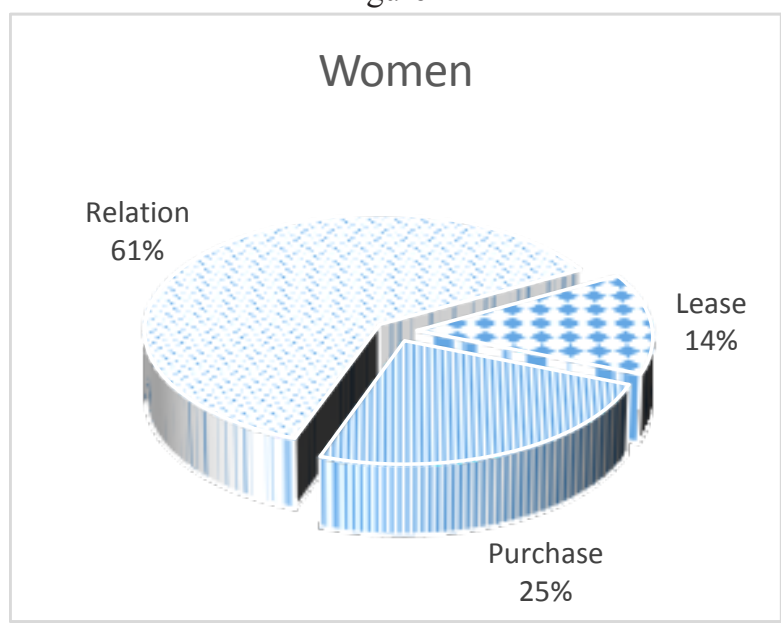

Figure 5

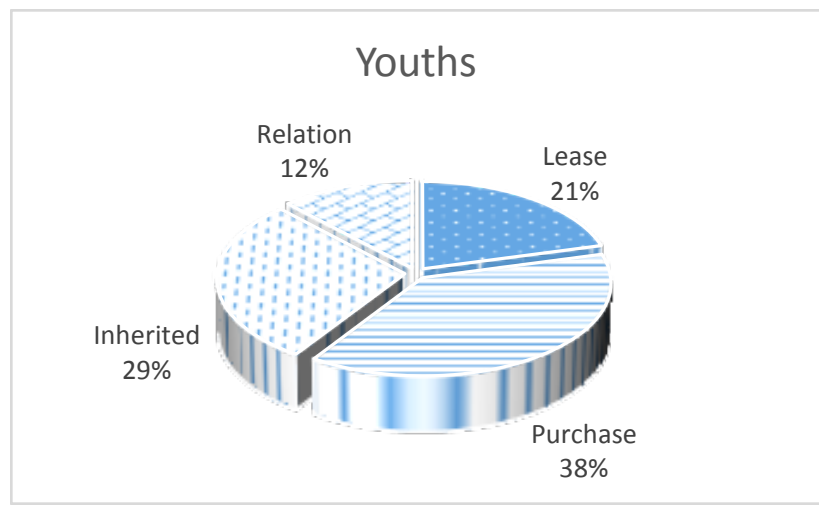

Figure 6

Figure 4-6. Access to land used for pond construction

\subsection{Gender roles in table-size fish farming}

The results for gender roles in fish farming is presented in table 3. From the table, the roles of pond digging/ construction of dykes were carried out by the men and male youths. More so, the male youths and men dominate in fingerling stocking and liming of ponds with ash. In pond management, the men, women and youths were actively involved in fish feeding, fish sampling and environmental cleaning. The role of women in post-harvest was limited to fish grading after harvest while the men and the male youths perform the functions of net preparation, fish harvest (dragging), grading and weighing. From the result, one can see that the women and female youths contribute to activities that are "light" in nature, while the men and male youths perform heavy tasks which require strength or vigor. This shows a key gender differences in division of labour as reported by Sexsmith (2017). This is because some roles may not fit well with women physique especially when their feminine nature is put into consideration. This gendered differences observed in the production chain could lead to an unequitable distribution of benefits among men, women and youths as reported by Farnworth Sultana, Kantor \& Choudhury (2015). This is because an entrepreneur will most likely pay higher remuneration to individuals who perform greater tasks such as; pond digging/construction of dykes and harvesting than those individuals performing lesser/light functions such as; feeding and environmental cleaning. This gives credence to Jahan et al. (2015) survey in Bangladesh who reported that women accept lower pay than men because they are short of alternatives. For this reason, unless other alternatives such as automation of the fish production process is adopted, the roles of women and female youths in fish farming value chain activities will continue to be limited to the functions observed in the study. 
Table 3. Gender roles in table-size fish farming

\begin{tabular}{|c|c|c|}
\hline Men & Women & Youths \\
\hline \multicolumn{3}{|c|}{ Preparation of Ponds/ Construction of Dykes } \\
\hline $\begin{array}{l}\text { Digging of ponds, } \\
\text { draining of water } \\
\text { and filling of bags } \\
\text { with sands for dykes }\end{array}$ & & $\begin{array}{l}\text { Male youths dig ponds, drain } \\
\text { water and fill bags with sands for } \\
\text { dykes }\end{array}$ \\
\hline \multicolumn{3}{|c|}{ Fish Stocking and Liming } \\
\hline $\begin{array}{c}\text { Fingerlings stocking } \\
\text { and liming of ponds } \\
\text { with ash }\end{array}$ & $\begin{array}{l}\text { Liming of ponds } \\
\text { with ash }\end{array}$ & $\begin{array}{l}\text { Male youths stock ponds with } \\
\text { fingerlings while both male and } \\
\text { female youths lime ponds with } \\
\text { ash }\end{array}$ \\
\hline \multicolumn{3}{|c|}{ Fish Management } \\
\hline $\begin{array}{l}\text { Fish feeding, fish } \\
\text { sampling and envi- } \\
\text { ronmental cleaning } \\
\text { Fish }\end{array}$ & $\begin{array}{l}\text { Fish feeding, } \\
\text { fish sampling } \\
\text { and environ- } \\
\text { mental cleaning } \\
\text { Harvest and Post- }\end{array}$ & $\begin{array}{l}\text { Male and female youths feed fish } \\
\text { and clean the farm environment } \\
\text { while male youths drag ponds } \\
\text { with nets for fish samplings } \\
\text {-harvest Activities }\end{array}$ \\
\hline $\begin{array}{l}\text { Preparation of nets, } \\
\text { dragging of fish, } \\
\text { grading and weigh- } \\
\text { ing }\end{array}$ & Grading & $\begin{array}{c}\text { Male youths prepare nets, drag } \\
\text { and weigh fish while both male } \\
\text { and female youths grade fish } \\
\text { after harvest }\end{array}$ \\
\hline
\end{tabular}

Source: Field Survey, 2020

\subsection{Perception on gender participation in table size fish farming activities}

The perception of table-size fish farmers on gender participation in is presented in Table 4. From the result of the analysis, the actors in the production chain indicated that most of the value chain activities require one with masculine disposition which ranked first with the mean $(=3.21)$. Priority given to masculinity is linked to the manual operation of the activities in the production chain, hence, this perception seems plausible since the roles played by women in table-size fish farming were those that can be classified as "light burden" functions. Morgan et al. (2015) reported that existing techniques employed in fish farming are not acceptable for women because of perceptions that roles associated in the use of such techniques are not gender sensitive. This is because the techniques employed to execute activities such as; pond digging, harvesting and weighing requires one with masculine disposition. The men and the male youths who possess such physical characteristics tend to participate more in this value chain. Also, the result show that women were perceived not to have access to land required for participation in table-size fish farming $(=2.65)$. This finding agrees with existing norm in the African tradition, that men have greater advantage and financial position to acquire land (Mabundza, Dlamini \& Nkambule, 2014). This is due to the advantages accorded to men by the local tradition and ancestral inheritance system which makes them have greater influence in decision making within the household and communities. The women may have access to land; however, their degree of access may differ with that of the men. Therefore, women need empowerment (policy, finance, advocacy) to enable them have increased access to land for fish farming. Thirdly, the result show that the actors in the production chain perceive that the skills involved are exclusively designed to the interest of men and youths $(=2.53)$, and that table-size fish farming is capital intensive $(=2.53)$. The importance of capital in table-size fish farming is quite enormous to meet the high operating cost associated with feeding and other requirements of the fish for at least six months of which most women do not have such financial strength to meet these demands.

Table 4. Perceptions of respondents on participation in table-size fish farming

\begin{tabular}{|c|c|c|c|c|}
\hline $\begin{array}{l}\mathrm{S} / \\
\mathrm{N}\end{array}$ & Perceptions & Mean & Rank & Inference \\
\hline 1. & $\begin{array}{l}\text { The skills involved are exclusively designed } \\
\text { to the interest of men and youths }\end{array}$ & 2.53 & $3^{\text {rd }}$ & Agree \\
\hline 2. & $\begin{array}{l}\text { Most of the value chain activities requires } \\
\text { one with masculine disposition }\end{array}$ & 3.21 & $1^{\text {st }}$ & Agree \\
\hline 3. & The value chain is capital intensive & 2.53 & $3^{\text {rd }}$ & Agree \\
\hline 4. & $\begin{array}{l}\text { Women don't have access to land required } \\
\text { for participation in this value chain }\end{array}$ & 2.65 & $2^{\text {nd }}$ & Agree \\
\hline
\end{tabular}

Source: field survey, 2020

\subsection{Estimation of cost and returns and gender gaps in aquaculture}

The result of the analysis of value of fixed assets, revenue and gender based employment for the men, women and youths in table-size fish farming is presented in table 5.1. The result of the analysis shows that the youths were the highest with about 2,088,667.9 worth of fixed assets followed by the men who had about 1,889,516.52 worth of fixed assets while the women were the least with about 1,264,221.42 worth of fixed assets. The amount is used in purchasing or installing fixed items such as land, construction of ponds, piping and accessories, pumping machine, borehole and other fixed assets such as nets, taps etc. The results imply that the men and youths have a higher value of fixed assets than the women probably because they have more investment on the number and sizes of ponds, fish stocked as well as access to capital than the women. This is supported by Ayodele et al. (2016) that there is significant difference in men and women access to production resources such as land, finance etc. This is because the men and youths had larger productive assets such as land used for large scale ponds for production than the women.

On revenue, the result shows that the men receive about $14,913,538.4$ as revenue per year, the women earn about $3,176,647.2$ as revenue per year and the 
youths earn about 9,972,308.1 as revenue per year. The difference in the revenue received by the men, women and youths could be largely attributed to the number of factors such as; number of ponds stocked with fish, quantity of fish harvested from ponds and market price of fish.

Information on gender based employees established that an average of 2.18 men and 2.73 youths were employed by the men involved in fish farming, while 1.3 men and 2.50 youths were employed by the women and 1.89 men and 2.90 youths were employed the youths in table-size fish farming enterprise in the area. Surprisingly, findings show that there is no woman employed in the table-size fish farming as paid labour, but that does not mean that women do not participate in the production chain as the study has established the roles of women in production chain especially in fish feeding and environmental cleaning (Tafida, Nwabeze \& Ayanda, 2011). Hence, women could be perceived to contribute as unpaid family labour in the table-size fish production chain in Kainji Lake Basin.

The cost and returns in table size fish farming is presented in Table 5.2. From the result of the analysis, the net-income for the men was 6233509.91 with $41.80 \%$ net profit margin while the women realize about N 1073576.33 net-income with $33.80 \%$ profit margin whereas, the net-income for the youths was 5206967.07

Table 5.1. Information on Value of fixed assets, Revenue and employment in table-size fish farming

\begin{tabular}{|c|c|c|c|c|c|c|c|c|c|}
\hline \multirow[b]{2}{*}{ ITEM } & \multicolumn{3}{|c|}{ Men } & \multicolumn{3}{|c|}{ Women } & \multicolumn{3}{|c|}{ Youths } \\
\hline & MN & MUP (\#) & TP (\$) & MN & MUP (\$) & TP ( $(\mathbb{N})$ & MN & MUP ( $\mathbf{N})$ & TP (\#) \\
\hline \multicolumn{10}{|l|}{ Fixed Assets } \\
\hline Cost of Land & 1.00 & 833548.38 & 833548.38 & 1.00 & 450000.00 & 450000.00 & 1.00 & 1077391.30 & 1077391.30 \\
\hline Borehole & 1.39 & 439534.88 & 610953.48 & 1.14 & 478571.42 & 545571.42 & 1.29 & 481081.08 & 620594.59 \\
\hline Pumping Machine & 1.00 & 139732.14 & 139732.14 & 1.00 & 149000.00 & 149000.00 & 1.00 & 138902.43 & 138902.43 \\
\hline Piping other assets & 1.00 & 124193.55 & 124193.55 & 1.00 & 78000.00 & 78000.00 & 1.00 & 97521.74 & 97521.74 \\
\hline \multicolumn{10}{|l|}{ Revenue } \\
\hline a) No. of Cycles/Yr & 1.84 & & & 1.80 & & & 1.83 & & \\
\hline b) $\mathrm{Kg} /$ pond & 1941.93 & & & 1640.00 & & & 1930.43 & & \\
\hline c) Price/Kg & & 630.48 & & & 633.00 & & & 632.93 & \\
\hline \multicolumn{10}{|l|}{ Revenue/year } \\
\hline$=\mathbf{a} * \mathbf{b} * \mathbf{c} *$ MN ponds & & & 14913538.4 & & & 3176647.2 & & & 9972308.1 \\
\hline Men & 2.18 & 12269.23 & 26746.92 & 1.33 & 14000.00 & 18620.00 & 1.89 & 11888.89 & 22470.00 \\
\hline Women & 0.00 & 0.00 & 0.00 & 0.00 & 0.00 & 0.00 & 0.00 & 0.00 & 0.00 \\
\hline Youths & 2.73 & 9654.54 & 26356.89 & 2.50 & 10625.00 & 26562.5 & 2.90 & 9804.87 & 28434.12 \\
\hline
\end{tabular}

Source: Computation from field survey, 2020

Note: $\mathrm{MN}=$ Mean Number; MUP=Mean Unit Price/Cost; $\mathrm{TP}=$ Total Price/Cost; TW/M=Total Wage per Month; Qty=Quantity

Table 5.2. Cost and returns in table-size fish farming per two cycles in a year

\begin{tabular}{|c|c|c|c|}
\hline Items & Men (A) & Women (A) & Youths (N) \\
\hline Revenue from sales & 14913538.4 & 3176647.2 & 9972308.1 \\
\hline \multicolumn{4}{|l|}{ Expenses } \\
\hline Cost of feed & 6986065.57 & 1260800.00 & 3511282.61 \\
\hline Fertilizer/cow dungs & 9089.52 & 2660.00 & 5089.13 \\
\hline Salt/ash & 2579.06 & 2063.16 & 2361.11 \\
\hline Electricity bill/year & 37786.77 & 28500.00 & 35503.44 \\
\hline Depreciation & 40052.03 & 31312.25 & 40151.03 \\
\hline Fueling & 124327.13 & 32476.68 & 53763.24 \\
\hline Transport & 89633.33 & 59623.35 & 61573.44 \\
\hline Levies & 24823.15 & 16845.43 & 18245.89 \\
\hline Labour & 637245.70 & 542190.00 & 610849.40 \\
\hline Total & 8680028.49 & 2103070.87 & 4765341.03 \\
\hline Net income $=$ Revenue-expenses & 6233509.91 & 1073576.33 & 5206967.07 \\
\hline Net Profit Margin & $41.80 \%$ & $33.80 \%$ & $52.21 \%$ \\
\hline Return on Investment & $71.81 \%$ & $51.05 \%$ & $109.27 \%$ \\
\hline Benefit Cost Ratio (BCR) & 1.72 & 1.51 & 2.09 \\
\hline
\end{tabular}

Source: Computation from field survey, 2020 
with $52.21 \%$ profit margin. This shows that the men and youths earn more than the women in table-size fish farming largely due to the numbers ponds stocked with fish by the men, women and youths and partly due to the level of technical know-how. Moreover, it indicates that fish farming is a lucrative enterprise as supported by Omobepade et al. (2015) and Adeosun et al. (2019) that aquaculture is a viable business. This is because the Return on Investment was $71.81 \%, 51.05 \%$ and $109.27 \%$ for the men, women and youths respectively implying that to every 1 invested in table-size fish farming, about 77.38 kobo (average value) will be realized as profit ceteris paribus.

The gender gap ratio of table-size fish farmers (Table 5.3) shows that the ratio in terms of the value of fixed assets between the men and women was 0.67 , the ratio between the men and youths was 0.90 and the ratio between the women and youths was 0.61 . This indicates that the difference in the value of fixed assets between the men and women as well as between the women and youths is quite larger than the difference in value of fixed assets between the men and youths. However, in terms of revenue, the ratio between the men and women was 0.21 , the ratio between the men and youths was 0.67 and the ratio between the women and youths was 0.38 . This means that there is unequal revenue generated by the men, women and youths which is as largely due to the number of ponds used in fish farming. Also, it implies that there is gross inequality in the revenue realized between the men, women and youths in table-size fish farming. The ratio for employees between the men and youths was 0.31 which indicates the extent of inequality in terms of number of paid labour in table-size fish farming in the area. More so, the results show that the ratio between men and youths in terms of wage paid was 0.79 which means that there is no great inequality in the amount paid to men and youths employed in table-size fish farming in the area. From the result of the ratio analysis, it is obvious that there is an existing gender-based power differences in aquaculture which has been the major issue with gender (Paul \& Meena, 2016). Most importantly, access and use of production resources is key to high productivity and profits. However, unequal access to these resources by men, women and youths in aquaculture will definitely lead to variations in outputs and profits. Generally, gender differences in access to agricultural production resources have been a very serious concern in many developing countries around the world (Oladosu, Afolabi \& Buhari, 2018). This calls for empowerment in aquaculture by NGOs, governments and other funding agencies to effectively target the vulnerable groups (women and youths) in their interventions for aquaculture development in Nigeria.

\section{Conclusion and Recommendations}

The study established that men and youths used personal savings to invest in aquaculture as well as acquired land used for pond construction through purchase or inheritance while family relations were instrumental in financing women in fish farming. Majority of the roles in aquaculture were performed by the men and male youths while the women were actively involved in fish management. Also, the net-income realized from aquaculture shows that the men receive a higher net-income than the women and youths due to the higher level of investment in aquaculture by the men. Based on the findings of the study, it is recommended that women should be organized in groups for empowerment. This will enable them utilize

Table 5.3. Gender gaps in table-size fish farming

\begin{tabular}{|c|c|c|c|}
\hline Indicators & Absolute Gender Gap & Relative Gender Gap (\%) & Gender Gap Ratio \\
\hline \multicolumn{4}{|l|}{ Value of Fixed Assets } \\
\hline Men \& Women & 625,295 & 49.46 & 0.67 \\
\hline Men \& Youths & 199,151 & 10.54 & 0.90 \\
\hline \multicolumn{4}{|l|}{ Revenue } \\
\hline Men \& Women & $11,736,891$ & 369.47 & 0.21 \\
\hline Women \& Youths & $6,795,661$ & 213.93 & 0.38 \\
\hline \multicolumn{4}{|l|}{ Employees } \\
\hline Men \& Women & 1.80 & 0.00 & 0.00 \\
\hline Men \& Youths & 0.90 & 50.56 & 0.66 \\
\hline Women \& Youths & 2.71 & 0.00 & 0.00 \\
\hline \multicolumn{4}{|l|}{ Wage } \\
\hline Men \& Youths & 2691.24 & 26.84 & 0.79 \\
\hline Women \& Youths & 0.00 & 0.00 & 0.00 \\
\hline
\end{tabular}

Source: computation from field survey, 2020 
their collective strength through division of labour in fish farming.

\section{Acknowledgment}

This study received its financial support from the Research and Technical division of National Institute for Freshwater Fisheries Research, New Bussa Niger State, Nigeria. Also, the technical contribution of Agricultural Development Programmes (ADPs), New Bussa unit in identifying and ensuring that all ethical procedures were dully considered before data were collected is hereby recognized.

\section{Ethical Aspects}

The study ensured that all necessary ethical aspects were considered before data collection. The instruments for data collection were thoroughly vetted by experts from the Division of Socio-economic and Extension Services, National Institute for Freshwater Fisheries Research. Also, clearance for data collection was granted by the state department of Agricultural Development Programme (ADP). Prior to data collection, the ADP extension agents sensitized the respondents on the purpose of the research by highlighting the key data required from them. In addition, the respondents were guaranteed that the information provided will be strictly confidential.

\section{References}

[1] Adeosun, K. P., Ume, C.O. \& Ezugwu, R. U. (2019). Analysis of socio-economic factors of fish pond production in Enugu State, Nigeria. Journal of Tropical Agriculture, 57(1), 27-34.

[2] Aguihe, E. O., Sule, A. M. \& Olowosegun, T. (2013). Role of gender in breeding and management of improved catfish in Kainji Lake Basin: 2012/2013 Annual report of National Institute for Freshwater Fisheries Research, New Bussa, Niger State. New Bussa, Niger State.

[3] Akarue, O. B. \& Aregbor O. E. (2015). Socio- economic analysis of catfish farming in Uvwie Local Government Area, of Delta State, Nigeria. International Journal of Innovative Agriculture \& Biology Research, 3(3), 33-43.

[4] Ayodele, O.V., Fasina, O.O. \& Awoyemi, A. O. (2016). Gender analysis of cocoa farmers' access to production resources in Ekiti State, Nigeria. Applied Tropical Agriculture Volume, 21(3), 131-137.

[5] Brugere, C. \& Williams, M. (2017). Profile: Women in Aquaculture. Retrieved from https://genderaquafish.org/portfolio/women-in-aquaculture/
[6] Chandio, A. A., Yuansheng, J., Sahito, J. G. M. \& Larik, S. A. (2016). Impact of formal credict of agricultural output: Evidence from Pakistan. African Journal of Business Management, 10(8), 162-168.

[7] Farnworth, C. R., Sultana, N., Kantor, P. \& Choudhury, A. (2015). Gender integration in aquaculture research and technology adoption processes: Lessons learned in Bangladesh. Penang, Malaysia.

[8] Ferrer, A. J. G., Perez, M. L., Roxas, A. T. \& Avila, E. M. (2014). Expanding roles of men and women in aquatic agricultural systems in the Philippines. Gender in Aquaculture and Fisheries: Navigating Change. Asian Fisheries Science Special Issue, (27), 185-194.

[9] Food and Agriculture Organization Statistics [FAOSTAT]. (2020). Statistics gender and land rights database.

[10] Food and Agriculture Organization [FAO]. (2011). The role of Women in Agriculture. Prepared by the SOFA Team and Cheryl Doss (No. 11-02). P. 1-34

[11] Gallant, M. (2019). Understanding gendered preferences for Climate-Smart Agriculture adoption in Malawi. University of Ottawa, Canada.

[12] Gambo, D., Zahran, B. B.H. \& Sidahmed, M. B. B. A. (2016). Socio-economic factors influencing the participation of the marginalized and vulnerable farmers in the IFAD - Community based Agriculture and Rural Development Programme in Katsina State, Nigeria. Journal of Resources Development and Management, 24, 50-57.

[13] Harrison, R., Leitch, C. \& McAdam, M. (2016). Identity work and the development of entrepreneurial leadership: does gender matter? In \& C. H. T. Nelson, K. Lewis (Ed.), Global female entrepreneurship handbook. London: Routledge.

[14] Ifejika, P. I., Asadu, A. N., Enwelu, I.A., Sanni, A. O., Nwabeze, G. O. \& Omeje, J. (2015). Determining youth choice of enterprise in aquaculture production for job creation in Abia State, Nigeria. Nigerian Journal of Fisheries, 12(1), 809-914.

[15] Jahan, K. M., Belton, B., Ali, H., Dhar, G. C. \& Ara, I. (2015). Aquaculture technologies in Bangladesh: An assessment of technical and economic performance and producer behavior. Penang, Malaysia.

[16] Kenya Market-Led Aquaculture Programme [KMAP]. (2016). Gender impact Study Submitted by ETC East Africa to Farm Africa. P. 24.

[17] Kruijssena, F., McDougallb, C. L. \& van Asseldonk, I. J. M. (2018). Gender and aquaculture value chains: A review of key issues and implications for research. Aquaculture, 493, 328-337

[18] Kumar, G., Engle, C. \& Tucker, C. (2018). Factors 
driving aquaculture technology adoption. Journal of World Aquaculture Society, 49, 447-476.

[19] Lentisco, A. \& Lee, R. U. (2015). A review of women's access to fish in small-scale fisheries.

[20] Mabundza, M., Dlamini, C. S. \& Nkambule, B. (2014). Gender mainstreaming in smallholder agriculture development: A global and African overview with emerging issues from Swaziland. African Journal of Agricultural Research, 9(42), 3164-3170. Retrieved from https://academicjournals.org/article/ article1413208833 Mabundza et al.pdf

[21] Manyung-Pasani C. L., Hara, M. \& Chimatiro, S. (2017). Women's participation in fish value chains and value chain governance in Malawi: A case of Msaka (Lake Malawi) and Kachulu (Lake Chilwa). Retrieved from http://hdl.handle.net/10566/4526

[22] Maltschnig, E., Pailer, U., Sirlinger, G. \& Waltner, E. (2015). Gender-sensitive statistics: Making life's realities visible. Vienna Statistics Journal, 2(2014), 1-49. Retrieved from https://www.wien.gv.at/statistik/pdf/genderstatistics-english.pdf

[23] Morgan. M., Choudhury, A., Braun, M., Beare, D., Benedict, J. \& Kantor, P. (2015). Enhancing the gender-equitable potential of aquaculture technologies: CGIAR Research Program on Aquatic Agricultural Systems (AAS-2015 No. 07). Penang, Malaysia.

[24] Ogunmefun, S. O. \& Achike, A. I. (2017). Socioeconomic characteristics and constraints of pond fish farmers in Lagos State, Nigeria. Agricultural Science Research Journal, 7(10), 304 - 317.

[25] Omeje, J. E., Achike, A. I., Arene, C. J., Ifejika, P. I. \& Ifeijika, L. I. (2020). Participation of stakeholders in aquaculture value chain of the West Africa Agricultural Productivity Programme in Nigeria. Journal of Agricultural Extension, 24(4), 39-52.

[26] Omeje, J. E., Nwabeze, G. O., Ifejika, P. I., Faleke, S. A. \& Jimmy, S. P. (2018). Assessment of Agricultural Credit Guarantee Scheme Fund to Fisheries Sub-sector of Agriculture in Nigeria, 1982-2014. In 33rd Annual conference of fisheries society of Nigeria (pp.
375-377). Lagos.

[27] Omobepade, B.P., Adebayo, O. T., Amos, T.T \& Adedokun, B. C. (2015). Profitability analysis of aquaculture in Ekiti State, Nigeria. Nigerian Journal Agric. Food Environ., 11(1), 114-119.

[28] Oladosu, I. O., Afolabi, J. O. \& Buhari, A. K. (2018). Gender differentials in the accessibility of agricultural production resources among yam farmers in Saki Agricultural Zone of Oyo State, Nigeria. Journal of Agricultural Science and Food Research, 9(1), 1-4. Retrieved from https://www.longdom.org/open-access/gender-differentials-in-the-accessibility-of-agricultural-productionresources-among-yam-farmers-in-saki-agricultural-zone-of-oyo-s.pdf

[29] Paul, P. \& Meena, B. S. (2016). A study on access to and control over resources: Gender perspective. International Journal of Science, Environment and Technology, 5(5), $2982-2988$.

[30] Quddus, M. A., Jui, N.Z. Rahman, K.M.M. \& Rahman, M. (2017). Gender role in pond fish culture in terms of decision making and nutrition security. Bangladesh J. Agric. Econs., XXXVIII(1\&2), 55-71.

[31] Sexsmith, K. (2017). Promoting Gender Equality in Foreign Agricultural Investments: Lessons from voluntary sustainability standards. Winnipeg: IISD. Retrieved from https://www.iisd.org/sites/default/files/ publications/promoting-gender-equality-foreign-agricultural-investments.pdf

[32] Tafida, A. A., Nwabeze, G. O. \& Ayanda, J. O. (2011). Fish marketing in Kainji Lake. In M. . Raji, A, Okaeme, A.N \& Ibeun (Ed.), Forty years on Lake Kainji Fisheries Research (1st ed., pp. 104-113). New Bussa, Niger State: National Institute for Freshwater Fisheries Research.

[33] Ukpe, U. H., Audu, N. D., Djomo, C. R. F. \& Akise, O. G. (2017). Economics of catfish farming in selected Local Government Areas of Taraba State, Nigeria. Innovative Techniques in Agriculture, 2.3(2017), 376-382. 